\title{
Analisa Perencanaan Backhaul Untuk Jaringan Long Term Evolution (LTE) Di kota Yogyakarta
}

\author{
Muhammad Azhar ${ }^{1}$, Zein Hanni Pradana ${ }^{2}$, Ade Wahyudin ${ }^{3}$ \\ Program Studi S1 Teknik Telekomunikasi, Institut Teknologi Telkom Purwokerto \\ Fakultas Teknik Elektro, Institut Teknologi Telkom Purwokerto
}

\begin{tabular}{l} 
Informasi Makalah \\
\hline Dikirim, 24 Juli 2018 \\
Direvisi, 31 Oktober 2018 \\
Diterima, 31 Oktober, 2018 \\
\hline Kata Kunci: \\
Long Term Evolution \\
Backhaul \\
Microwave \\
Reference Signal Receive \\
Power. \\
Availability
\end{tabular}

\section{Keyword:}

Long Term Evolution

Backhaul

Microwave

Reference Signal Receive

Power

Availability

\begin{abstract}
INTISARI
Pelayanan telekomunikasi sangat berperan penting dalam kehidupan modern. Perkembangan Teknologi LTE di kota sangat tinggi. Selaku Operator memerlukan adanya backhaul yang handal namun juga efisien dari transmisi maupun dari segi kapasitas. Backhaul adalah suatu jalur yang menghubungkan dari suatu Base Station ke Base Station lain atau dari suatu Base Station ke core network untuk mengambil trafik dari Base Station tersebut. Penelitian ini membahas tentang analisa perencanaan backhaul untuk jaringan Long term Evolution di kota Yogyakarta. Dengan menggunakan Microwave sebagai teknologi Backhaul, dengan Frekuensi $1800 \mathrm{MHz}$ agar dapat mengakomodasi trafik di kota Yogyakarta dengan menggunakan perencanaan capacity maupun coverage. Dari hasil perencanaan Jaringan Long Term Evolution menggunakan Frekuensi 1800 $\mathrm{MHz}$ Nilai Rereference Signal Receive Power (RSRP) didapat dari hasil simulasi dari Parameter Long Term Evolutin adalah adalah rata-rata sebesar -75.66 dBm Sedangkan Pada Perencanaan Backhaul Menggunakan Teknologi Microwave diperoleh rata-rata daya terima $>-78 \mathrm{dBm}$ dan nilai Availability $>99,999 \%$ untuk link dibawah jarak $<1,7 \mathrm{~km}$. Sehingga dapat diambil Kesimpulan Bahwa Backhaul Dengan Teknologi Microwave Pada penelitian ini bekerja dengan baik dan Optimal dapat menghubungkan Jaringan LTE di Kota Yogyakarta dengan Jarak $<1,7$ km. Perencanaan ini dilakukan menggunakan atoll 3.3.
\end{abstract}

\begin{abstract}
Telecommunication services play an important role in modern life. The development of Long Term Evolution technology in the city is very high. As Operator Requires a reliable backhaul but also efficient from the transmission and in terms of capacity. Backhaul is a path that connects from a base station to another base station or from a base station to the core network to extract the traffic from the base stations. This research discusses about analysis planning backhaul for Long Term Evolution Network In Yogyakarta, by using microwave as backhaul technology, which its frequency $1800 \mathrm{MHz}$ in order to accommodate traffic in the city of Yogyakarta by using capacity planning and coverage. In Long Term Evolution Network planning results using frequency $1800 \mathrm{MHz}$ Rereference Signal Receive Power (RSRP) value obtained from simulation results from Long Term Evolution parameters is an average of $-75.66 \mathrm{dBm}$ while on backhaul planning using microwave technology obtained average receive power $>-78 \mathrm{dBm}$ and availability value $>99.999 \%$ for links below $<1.7 \mathrm{~km}$ distance. So that can be taken conclusion that backhaul with microwave technology in this research work well and optimal, it can connect LTE network in Yogyakarta City with distance $<1.7 \mathrm{~km}$. This planning is done using atoll 3.3 .
\end{abstract}

\section{Korespondensi Penulis:}

Muhammad Azhar

Program Studi S1 Teknik Telekomunikasi

Institut Teknologi Telkom Purwokerto

JL. DI Panjaitan No.128 Purwokerto, 53147

Email: 16101239@ittelkom-pwt.ac.id 


\section{PENDAHULUAN}

Perkembangan Teknologi telekomunikasi di dunia semakin berkembang pesat. Pada masa kini kebutuhan layanan data bergerak dan laju yang semakin tinggi sehingga di perlukannya suatu jaringan yang handal yang dapat mengirimkan data dengan kecepatan tinggi sehingga mendukung semua fitur layanan yang ada, Teknologi Long Term Evolution (LTE) jaringan seluler yang bekembang pada saat ini.Guna mendapatkan jaringan LTE dengan kecepatan yang stabil dan handal, juga diperlukan backhaul atau penghubung antar eNodeB yang handal. Tujuan dari skripsi ini adalah merancang jaringan backhaul untuk sistem komunikasi 4G LTE di Kota Yogyakarta. semakin banyaknya pengguna seluler maka sangat mendukung dengan dikembangkannya suatu teknologi seluler seperti LTE dengan microwave sebagai backhaul. Hasil yang akan dicapai pada perancangan jaringan backhaul untuk sistem komunikasi 4G LTE ini yaitu dapat memenuhi throughput LTE pada kota Yogyakarta.

Pada Penelitian sebelumnya yaitu Perancangan Jaringan Backhaul Untuk Sistem Komunikasi 4g Long Term Evolution (LTE) Di Jakarta Area Kalideres. membuat Perencanaan secara cakupan dan kapasitas dan melakukan simulasi Perancangan LTE menggunakan frekuensi $1800 \mathrm{MHz}$ menggunakan Atoll, dengan Parameter yang diamati Reference Signal Received Power. Kemudian Perancangan Backhaul Microwave dan Parameter yang diamati untuk melakukan perhitungan Link budget pada parameter Free Space Loss, Receive Signal Level, Fading Margin. Kekurangan Pada penelitian ini Perencanaan Secara cakupan yang artinya hanya berdasarkan cakupan daerah atau coverage tidak efektif karena secara kapasitas lebih baik berdasarkan jumlah EnodeB yang didapat dan berdasarkan Trafik yang akan dilayani.Kemudian Pada penelitian tidak ada Parameter yang diamati dari perencanaan Backhaul seperti quality objective dan Availability.

Oleh karena itu Penulis mengambil judul "ANALISA PERENCANAAN BACKHAUL UNTUK JARINGAN LONG TERM EVOLUTION (LTE) DIKOTA YOGYAKARTA” Peneliti bermaksud membuat perencanaan secara cakupan dan kapasitas. Perencanaan LTE Menggunaan Frekuensi $1800 \mathrm{MHz}$ dan Mensimulasikan Perencanaan Long Term Evolution (LTE) Berdasarkan Kapasitas agar trafik yang ada di Kota Yogyakarta bisa terlayani. Kenapa menggunakan Perencanaan Kapasitas karena berdasarkan Trafik dan jumlah Enode yang didapatkan. Paramater yang diamati pada Perencanaan LTE yaitu Reference Signal Received Power (RSRP) untuk Melihat seberapa jauh daya sinyal yang dapat menjangkau daerah perencanaan. Perencanaan Backhaul microwave menggunakan software atoll dan perhitungan link budget pada backhaul microwave dengan menggunakan Parameter Line Of sight, Free Space Loss, Receive Signal Level, Fading Margin,Availability dan Quality Objective

\section{METODOLOGI PENELITIAN}

Penelitian ini dilakukan dari tahapan melakukan perencanaan jaringan akses Long Term Evolution , dalam perencanaan jaringan akses terdapat dua jenis perencanaan yaitu capacity planning yaitu perencanaan secara kapasitas dan coverage planning atau perencanaan secara cakupan. Untuk mendapatkan jumlah estimasi site yang digunakan maka langkah awalnya dengan untuk mendapatkan besarnya nilai network throughput yaitu membuat klasifikasi dan estimasi jumlah pelanggan pada wilayah perencanaan. Wilayah perencanaan yang diambil yaitu Kota Yogyakarta. Coverage Planning meliputi perhitungan path loss link budget yaitu untuk mengetahui pelemahan sinyal yang terjadi antara user dengan eNodeB. Sehingga dapat ditentukan maksimal jarak antar eNodeB. Data yang diperlukan untuk klasifikasi dan estimasi jumlah pelanggan antara lain luas wilayah masing-masing kecamatan yang berada di kota Yogyakarta, data penduduk, dan penetrasi pengguna seluler. Klasifikasi daerah layanan dilakukan berdasarkan kepadatan penduduk. Sedangkan estimasi jumlah pelanggan dilakukan berdasarkan market share dari operator seluler yang akan diteliti. Langkah berikutnya adalah membuat klasifikasi model layanan yang akan diteliti. Kemudian melakukan perhitungan Single User Throughput dan Network Throughput. Setelah diperoleh kapasitas cell dan besarnya Network Throughput, langkah selanjutnya adalah menghitung jumlah cell atau site yang dibutuhkan. Untuk kemudian dilakukan simulasi menggunakan software Atoll 3.3. 


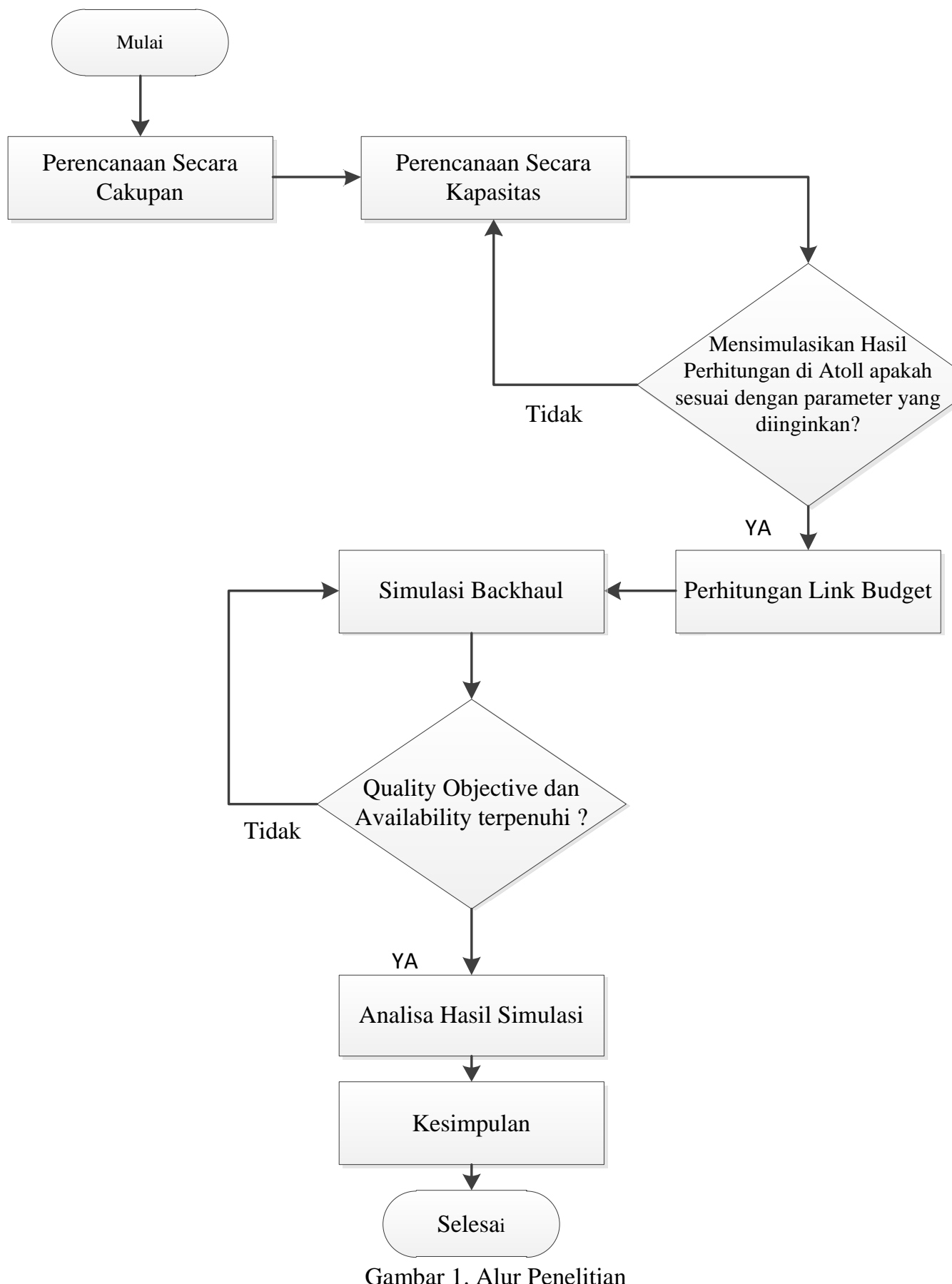

Perencanaan yang kedua adalah perencanaan jaringan backhaul dalam Penelitian kali ini jaringan backhaul yang dimaksud adalah untuk menghubungkan antar eNodeB, sehingga eNodeB dapat secara optimal melayani pengguna. Perencanaan backhaul dimulai setelah perencanaan jaringan akses selesai dilakukan, perencanaan jaringan backhaul dilakukan perhitungan link budget seperti perhitungan Line Of Sight (LOS) .Fresnel Zone ,Free Space Loss (FSL), Effective Isotropic Radiated Power (EIRP), Receive Signal Level (RSL), Fading Margin, Nilai Quality Objective dan Availability. Perencanaan ini dilakukan di kota Yogyakarta. Kota Yogyakarta terletak pada posisi 110 21’52 s/d 11036 44” Bujur Timur dan 7 48’5 ” s/d 7 80’13” Lintang Selatan dan merupakan dataran rendah dengan ketinggian rata-rata lebih dari 113 meter di atas permukaan laut. Berdasarkan Data BPS, planning yang akan dilakukan pada wilayah Kota Yogyakarta adalah 32,50 km2. Jumlah populasi penduduk di kota Yogyakarta sekitar 417.744 jiwa. Kota Yogyakarta dihuni oleh penduduk yang tersebar di 14 desa. Penyebaran penduduk di tiap-tiap kecamatan dapat dilihat pada tabel 1 adalah jumlah penduduk secara keseluruhan yang nantinya akan dilakukan filter terhadap penduduk yang berusia produktif (di atas 16 tahun). 
Perhitungan radio link budget perlu dilakukan pada saat proses perencanaan, gunanya adalah untuk mengetahui pelemaahan sinyal maksimum yang masih diperbolehkan antara antena eNodeB dengan antena UE atau yang biasa disebut dengan Maximum Allowable Path Loss (MAPL).[1]

$R X E F S=R X F S-G R x+L R X \_L L$

Keterangan :

RXFS = Rx Faded Sensitivity $(\mathrm{dBm})$

GRX = Gain Antenna Rx $(\mathrm{dBi})$

LRX_LL = Rx Line Loss (dB)

Setelah menentukan EIRP dan RXEFS maka persamaan MAPL arah downlink adalah sebagai berikut:

MAPL = TX EIRP - RXEFS - LBV - Minterference- MSF

Keterangan:

EIRP = Effective Isotropic Radiated Power $(\mathrm{dBm})$

RXEFS = Effective Rx Faded Sensitivity $(\mathrm{dBm})$

LBV = Loss Body, Vehicle, Building (dB)

Minterference $=$ Interfernce Margin $(\mathrm{dB})$

MSF $=$ Log Normal Margin (dB)

Kemudian Melakukan Perhitungan secara kapasitas dengan Menggunakan Persamaan[2]

$\mathrm{GF}=\frac{\sum \text { Pertumbuhan Penduduk }}{\sum \text { Tahun }}$

Berikut persamaan untuk menghitung proyeksi penduduk tahun ke-n.

$\mathrm{Pn}=\mathrm{Po}(1+\mathrm{GF})^{\mathrm{n}}$

Untuk menghhitung jumlah user LTE operator X dapat menggunakan persamaan total target user berikut.

Total target $u s e r=\mathrm{Pn} \times \mathrm{A} \times \mathrm{B} \times \mathrm{C}$

Keterangan :

Un = Jumlah penduduk tahun ke-n

A = Jumlah penduduk usia penetrasi pengguna seluler

$\mathrm{B}=$ Market share operator $\mathrm{X}$

$\mathrm{C} \quad=$ Penetrasi user LTE operator $\mathrm{X}$

Tabel 1. Data statistik dan Penduduk[3]

\begin{tabular}{lcl}
\hline \multicolumn{1}{c}{ Parameter } & Nilai & \multicolumn{1}{c}{ Keterangan } \\
\hline Jumlah Penduduk & 417744 & Tahun 2016 \\
Penduduk Usia Produktif (2016) & 309073 & $74 \%$ dari jumlah penduduk \\
Pertumbuhan Penduduk & $1,2 \%$ & Forecast untuk 5 tahun \\
Market Share & $42 \%$ & Operator X \\
Penetrasi LTE & $90 \%$ & Asumsi
\end{tabular}

Setelah melakukan Perencanaan LTE kemudian Melakukan Perencanaan Jaringan Backhaul Dengan Teknologi Microwave, Melakukan Perhitungan Link Budget dengan Parameter Berupa,Line Of sight, Free Space Loss,Effective Isotropic Radiated Power, Receive Signal Level, Fading Margin dan Nilai Quality Objective dan Availability.berikut persamaan-persamaan untuk Menghitung Link budget di sisi Microwave

Free Space Loss (FSL)

Free Space Loss merupakan fungsi jarak dan frekuensi. Free Space Loss adalah redaman yang sepanjang ruang antara antena pemancar dan penerima. Besarnya nilai free space loss dapat dicari dengan persamaan[4]

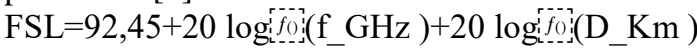

dengan,

FSL $\quad=$ Free Space Loss $(\mathrm{dB})$

$\mathrm{f} \quad=$ frekuensi $(\mathrm{Ghz})$

$\mathrm{D} \quad=$ jarak antara antena pemancar dan penerima $(\mathrm{km})$

Effective Isotropic Radiated Power(EIRP)

Effective Isotropic Radiated Power merupakan daya maksimum gelombang sinyal mikro yang keluar dari antena pemancar atau untuk menunjukan nilai efektif daya yang dipancarkan antena pemancar, dalam arti lain daya tersebut sudah mengalami penguatan. Besarnya Nilai EIRP didapat dengan Persamaan [5]

EIRP=P_Tx+G_ant-L_Tx. 
dengan,

EIRP = Effective Isotropic Radiated Power $(\mathrm{dBm})$

P_Tx = daya pancar $(\mathrm{dBm})$.

G_ant = Gain antenna (dBi)

L_Tx $=$ Transmitter loss $(\mathrm{dB})$

Received Signal Level (RSL)

Received Signal Level (RSL) adalah level daya yang diterima oleh piranti pengolah decoding. Rugirugi pada jalur di sisi antena penerima serta gain pada antena penerima memperoleh besar nilai RSL. Nilai RSL pada piranti pengolah decoding dapat dihitung dengan menggunakan persamaan .[6]

RSL=IRL-G_Rx-L_Rx

dengan,

RSL $=$ Received Signal Level $(\mathrm{dBm})$

$I R L=$ Isotropic Received Level $(\mathrm{dBm})$

$\mathrm{G} \_\mathrm{Rx}=$ Gain antenna (dBi).

$\mathrm{L} \_\mathrm{Rx}=$ Receiver Loss (dB).

Fading Margin (FM)

Fading Margin adalah Untuk mengatasi adanya fading, maka diperlukan cadangan daya yang digunakan agar dapat mempertahankan level daya terima di atas level batas ambang (threshold).Menghitung Fading Margin dengan menggunakan Persamaan

$F M=R S L-R x_{T H}$

dengan,

$\mathrm{FM} \quad=$ Fading Margin $(\mathrm{dB})$

$\mathrm{RSL} \quad=$ Receive Signal Level $(\mathrm{dBm})$

$R x_{T H} \quad=R x$ Threshold Level $(\mathrm{dBm})$

Availability

Availability adalah Ukuran kehandalan sistem sering disebut sebagai availability. Secara ideal, semua sistem harus memiliki availability 100\%. Tetapi hal tersebut tidak mungkin dipenuhi, karena dalam sistem pasti terdapat ketidakhandalan sistem unavailability. availability sering disebut juga dengan reliability yang didefinisikan dengan kemampuan sistem dalam memberikan pelayanan.

Availability dan Unavailability didapatkan dengan menggunakan rumus sebagai berikut [7]:

$A v=\left(1-U n A v_{\text {path }}\right) \times 100 \%$.

dengan,

UnAv= ketidakhandalan sistem

Av $=$ kehandalan sistem

Sedangkan unavailability dapat dinyatakan dengan persamaan 2.11:[7]

$U n A v_{\text {path }}=a \times b \times 2,5 \times f \times D^{3} \times 10^{-6} \times 10^{-F M / 10}$

dengan,

Unav $=$ ketidakhandalan sistem

$\mathrm{FM}=$ fading margin $(\mathrm{dB})$

$\mathrm{D}=$ panjang lintasan $(\mathrm{km})$.

$\mathrm{F}=$ frekuensi kerja $(\mathrm{GHz})$

$\mathrm{a}=$ faktor kekasaran bumi

a $: 1$ = daerah kekasaran rata-rata, dataran

a : 4 = daerah halus, laut, danau, dan gurun

a : $1 / 4=$ pegunungan dan dataran tinggi

$\mathrm{b}=$ faktor iklim

$\mathrm{b}: 1 / 4=$ daerah normal

b : $1 / 8=$ daerah pegunungan (sangat kering)

b : $1 / 2=$ daerah panas dan lembab

Dalam perencanaan menggunakan kondisi terburuk yaitu, b: 1

\section{HASIL DAN PEMBAHASAN}

Perancangan LTE dilakukan dikota Yogyakarta. Pada Penelitian ini menggunakan Perencanaan secara kapasitas. Dengan parameter yang diamati adalah Reference Signal Receive Power (RSRP) Hasil dari perencanaan menggunakan Atoll 3.3 dapat dilihat pada gambar 2 dan 3. 


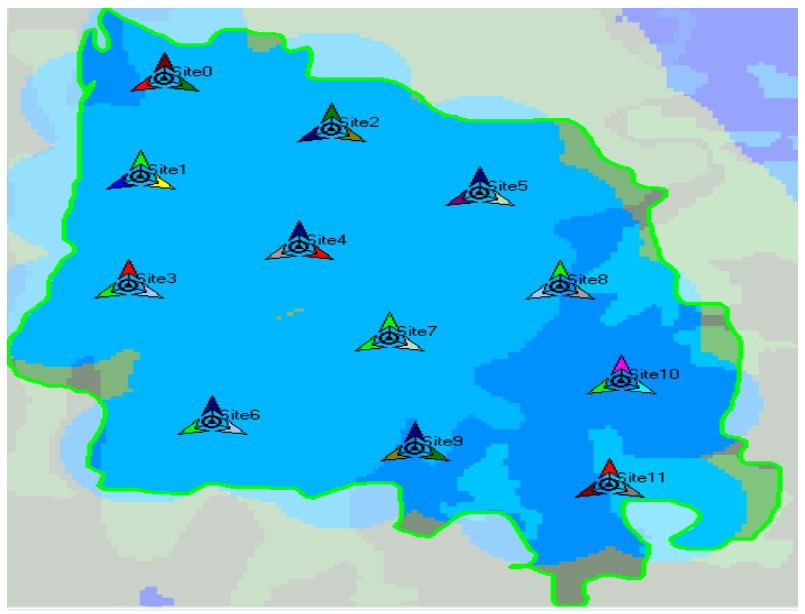

Gambar 2 Prediksi Reference Signal Receive Power (RSRP)

Terdapat 3 warna yang digunakan untuk menunjukan nilai RSRP dari simulasi, Pertama Biru muda ada kondisi RSRP yang bagus dengan nilai -70 dBm hingga -90 dBm,Kuning masuk ke dalam kondisi normal dengan nilai $-91 \mathrm{dBm}$ hingga -110 dBm sedangkan warna merah untuk kondisi buruk dengan nilai $-111 \mathrm{dBm}$ hingga $-130 \mathrm{dBm}$.

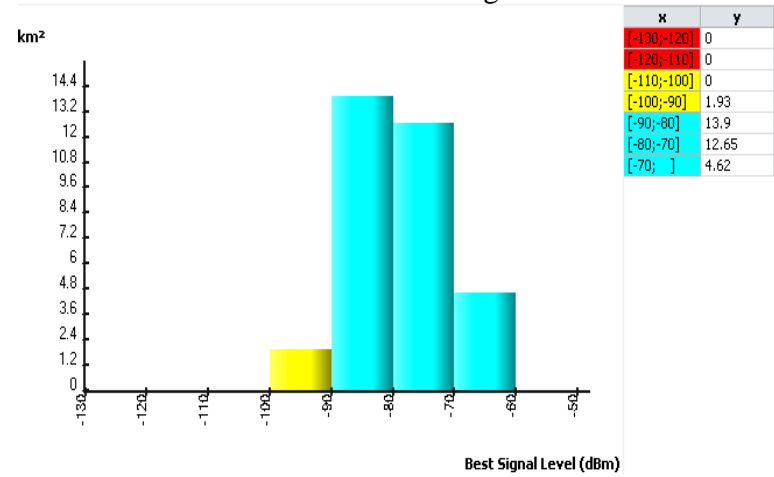

Gambar 3 Histogram RSRP

Histogram digunakan untuk mempermudahkan pembacaan nilai dari RSRP yang dihasilkan. Pada garis Vertikal menunjukkan nilai dari area yang dilayani $(\mathrm{km} 2)$ sedangkan Garis Horizontal menujukan Nilai dari Signal Level (dBm). Pada gambar 4.2 dapat dilihat bahwa Grafik warna biru muda memiliki rentang nilai -70 dBm sampai dengan -90 $\mathrm{dBm}$ melayani dengan luas daerah dengan sebesar 30, km2. Dan sisa dari grafik berwana kuning dengan nilai $-91 \mathrm{dBm}$ sampai dengan $-100 \mathrm{dBm}$ dengan luas daerah sebesar 1,93 km2. Dengan demikian pada Perencanaan menggunakan simulasi masih dalam kategori baik karena 30km2 area berada pada rentang nilai $-70 \mathrm{dBm}$ sampai dengan $90 \mathrm{dbm}$, dan sisa berada pada rentang nilai -91 dBm sampai dengan -100 dBm.

Kemudian Melakukan Perancangan Jaringan Backhaul dengan Teknologi Microwave. Terdapat 12 New site yang akan mengakomodasi trafik yang ada dikota Yogyakarta. Pada Perancangan Jaringan Backhaul ini Terdapat Quality Objective yang harus dipenuhi sebesar $-78 \mathrm{dBm}$ dengan standar perfomansi yang diingikan BER 10-6 dan Availability 99,999\%. Hasil Perancangan Backhaul microwave bisa dilihat pada gambar dibawah ini.

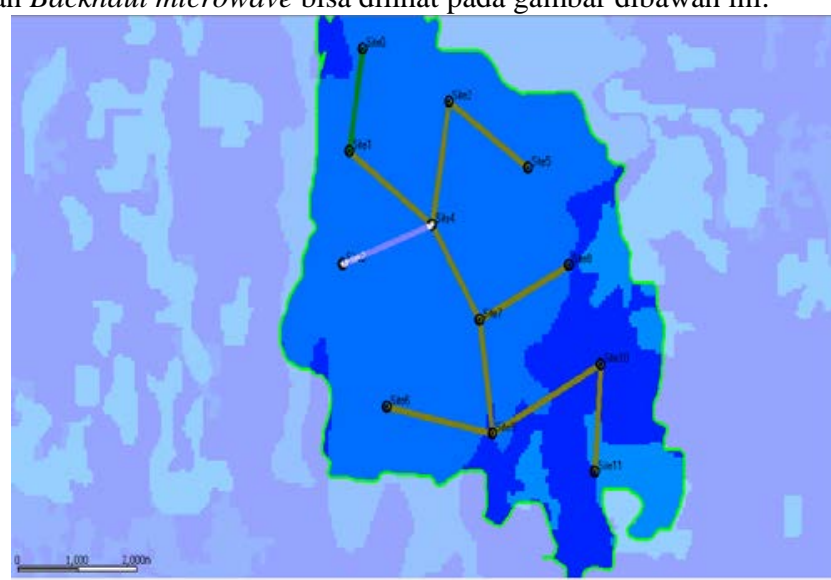

Gambar 3. Perancangan Jaringan Backhaul Microwave.

Techno Vol. 19, No. 2, Oktober 2018: $103-112$ 
Pada perencanaan ini link backhaul dibuat dengan topologi star dimana site 4 Menjadi site pengumpul atau Site agregasi. Site Agregasi adalah site yang digunakan untuk Menampung trafik dari Jaringan ENodeB untuk kemudian di transfer ke core. Penentuan Site 2 menjadi Site agregasi karena site 4 berada di tengah sehingga mudah untuk menghubungkan dengan site lain, dan diasumsikan site 4 mempunyai kapasitas terbesar antara EnodeB yang lain. Hasil report dari simulasi backhaul dapat di lihat dari tabel 3 Sebagai berikut :

Tabel 3. Hasil Report Simulasi

\begin{tabular}{lrrrr}
\hline Hop & FSL $(\mathrm{dB})$ & EIRP $(\mathrm{dBm})$ & \multicolumn{1}{l}{$\begin{array}{l}\text { RSL } \\
(\mathrm{dBm})\end{array}$} & \multicolumn{1}{c}{ FM(dB) } \\
\hline $0-1$ & 118.49 & 45.18 & -58.22 & 23.78 \\
$1-4$ & 120.44 & 45.18 & -60.19 & 21.81 \\
$3-4$ & 119.89 & 45.18 & -59.63 & 22.37 \\
$4-2$ & 120.1 & 45.18 & -59.85 & 22.15 \\
$4-7$ & 119.26 & 45.18 & -58.99 & 23.01 \\
$5-2$ & 119.84 & 45.18 & -59.58 & 22.42 \\
$6-9$ & 121.07 & 45.18 & -60.82 & 21.18 \\
$7-8$ & 120.25 & 45.18 & -59.99 & 22.01 \\
$7-9$ & 119.48 & 45.18 & -59.21 & 22.79 \\
$10-9$ & 122.02 & 45.18 & -61.79 & 20.21 \\
$10-11$ & 118.87 & 45.18 & -58.6 & 23.4 \\
\hline
\end{tabular}

Agar Perancangan Jalur transmisi di kota Yogyakarta pada semua link hop bekerja dengan baik dan optimal maka dibutuhkan Perhitungan link budget untuk mendapatkan nilai parameter yang menjadi tolak ukur keberhasilan dari suatu sistem transmisi. Pertama Melakukan Perhitungan tinggi antena. Perlunya ada Line of sight agar komunikasi antar microwave yang digunakan sebagai backhaul Karena apabila suatu Hop tidak LOS dapat menyebabkan menurunnya nilai dari availability atau bahkan dapat menyebabkan kegagalan dari link komunikasi tersebut Hasil Perhitungan Line of sight pada tabel 4 dibawah ini

\begin{tabular}{lrrrrrrrrrrrrr}
\multicolumn{11}{c}{ Tabel 4. Line Of sight } \\
\hline Hop & \multicolumn{1}{c}{ a } & b & c1 & c2 & c3 & c4 & \multicolumn{1}{c}{ C } & d1 & d2 & d & x & y \\
\hline $0-1$ & 129 & 113 & 0.02 & 134 & 0 & 2.40 & 136.43 & 0.42 & 0.93 & 1.35 & 10.0 & 13.49 \\
$1-4$ & 114 & 114 & 0.04 & 129 & 0 & 2.87 & 131.91 & 0.7 & 1 & 1.7 & 16.4 & 20.00 \\
$3-4$ & 108 & 114 & 0.02 & 130 & 0 & 2.28 & 132.31 & 0.33 & 1.26 & 1.59 & 30.0 & 21.25 \\
$4-2$ & 115 & 123 & 0.04 & 133 & 0 & 2.76 & 135.80 & 1.02 & 0.61 & 1.63 & 10.0 & 25.47 \\
$4-7$ & 114 & 102 & 0.03 & 134 & 0 & 2.71 & 136.75 & 0.71 & 0.77 & 1.48 & 41.0 & 15.00 \\
$5-2$ & 121 & 122 & 0.03 & 160 & 0 & 2.52 & 162.55 & 1.14 & 0.44 & 1.58 & 55.9 & 35.00 \\
$6-9$ & 92 & 88 & 0.03 & 125 & 0 & 2.52 & 127.55 & 1.41 & 0.41 & 1.82 & 35.0 & 51.20 \\
$7-8$ & 101 & 110 & 0.03 & 130 & 0 & 2.59 & 132.62 & 1.18 & 0.47 & 1.65 & 38.2 & 20.00 \\
$7-9$ & 102 & 88 & 0.02 & 120 & 0 & 1.97 & 121.99 & 0.23 & 1.28 & 1.51 & 23.4 & 15.00 \\
$10-9$ & 93 & 88 & 0.05 & 120 & 0 & 2.88 & 122.92 & 0.58 & 1.45 & 2.03 & 25.0 & 33.89 \\
$10-11$ & 93 & 87 & 0.02 & 115 & 0 & 2.39 & 117.41 & 1.01 & 0.4 & 1.41 & 25.5 & 30.00 \\
\hline
\end{tabular}

Pada Perhitungan mencari tinggi antenna sehingga mendapatkan keadaan LOS. Untuk Mencari tinggi antenna salah satu nilai antenna (Pengirim/penerima) ditentukan secara estimasi. Tinggi antena bervariasi antar link hop karena daerah dilalui setiap hop berbeda seperti pada link hop 5 -2 dan 6-9 dengan antena tertinggi karena obstacle didaerah tersebut paling tinggi.

Hasil Report dari backhaul juga dapat dihitung secara manual menggunakan Perhitungan Link budget seperti Free space Loss, Transmission Loss,Effective Isotropic Radiated Power, Receive Signal Level, Rx Threshold,Fading Margin dan Availability. Hasil Perhitungan link budget bisa dilihat pada tabel 5. 
Tabel 5. Perhitungan Link budget

\begin{tabular}{ccccc}
\hline Hop & FSL (dB) & EIRP(dB) & RSL (dBm) & FM(dB) \\
\hline $0-1$ & 118.58 & 65.87 & -16.83 & 61.17 \\
$1-4$ & 120.58 & 65.87 & -16.97 & 61.02 \\
$3-4$ & 120.00 & 65.87 & -17.32 & 60.68 \\
$4-2$ & 120.22 & 65.87 & -17.54 & 60.46 \\
$4-7$ & 119.38 & 65.87 & -16.70 & 61.30 \\
$5-2$ & 119.94 & 65.87 & -17.26 & 60.73 \\
$6-9$ & 121.17 & 65.87 & -18.49 & 59.50 \\
$7-8$ & 120.32 & 65.87 & -17.64 & 60.35 \\
$7-9$ & 119.55 & 65.87 & -16.87 & 61.12 \\
$10-9$ & 122.12 & 65.87 & -19.44 & 58.55 \\
$10-11$ & 118.96 & 65.87 & -16.28 & 61.72 \\
\hline
\end{tabular}

Pada tabel 3 dan 5 merupakan Hasil dari Simulasi dan Perhitungan link budget, akan tetapi terdapat sellisih dari beberapa parameter-paramter yang disebabkan karena berbeda nilai Dari EIRP dan RSL Pada Perhitungan dan Simulasi, akan tetapi Hasil dari Perhitungan dan Simulasi masih dikatakan bagus untuk nilai RSL atau daya terima sinyal berada Masih besar daripada nilai Threshold atau nilai ambang batas.

Quality objective dan Availability

Pada Parameter Quality Objective dan Availability merupakan Parameter utama dalam Perancangan Link backhaul adalah Quality Obcjective atau Nilai daya terima sinyal minimum yang harus dicapai suatu link sedangkan availability atau kehandalan sistem. Untuk menghitung Availability dapat di asumsikan frekuensi kerja yang digunakan sebesar $15 \mathrm{GHz}$ dan panjang lintasan dari Link hop 0-1 adalah 1,35 km serta besarnya nilai thermal fading margin adalah 61,17 dB, faktor kekasaran bumi adalah $1 / 4$ untuk daerah pegunungan dan dataran tinggi dan faktor iklim juga 1 untuk kondisi terburuknya. Hasil dari Quality objective dan availability bisa dilihat dari tabel 6. Dibawah ini.

Tabel 6. Hasil Availability dan Quality Objective

\begin{tabular}{|c|c|c|c|c|c|c|}
\hline \multirow{2}{*}{ Hop } & \multirow{2}{*}{$\begin{array}{c}\text { Availability } \\
\text { Objective (\%) }\end{array}$} & \multirow{2}{*}{$\begin{array}{l}\text { Quality Objective } \\
(\mathrm{dBm})\end{array}$} & \multicolumn{2}{|c|}{ Availability (\%) } & \multicolumn{2}{|c|}{ Quality $(\mathrm{dBm})$} \\
\hline & & & Simulasi & Perhitungan & Simulasi & Perhitungan \\
\hline $0-1$ & 99,999 & -78 & 99,999737 & 99,99999982 & $-58,22$ & $-16,83$ \\
\hline $1-4$ & 99,999 & -78 & 99,999216 & 99,99999963 & $-60,19$ & $-16,97$ \\
\hline $3-4$ & 99,999 & -78 & 99,99941 & 99,99999962 & $-59,63$ & $-17,32$ \\
\hline $4-2$ & 99,999 & -78 & 99,999339 & 99,99999959 & $-59,85$ & $-17,54$ \\
\hline $4-7$ & 99,999 & -78 & 99,999585 & 99,99999976 & $-58,99$ & $-16,70$ \\
\hline $5-2$ & 99,999 & -78 & 99,999424 & 99,99999963 & $-59,58$ & $-17,26$ \\
\hline $6-9$ & 99,999 & -78 & 99,998946 & 99,99999929 & $-60,82$ & $-18,49$ \\
\hline $7-8$ & 99,999 & -78 & 99,999293 & 99,99999958 & $-59,99$ & $-17,64$ \\
\hline $7-9$ & 99,999 & -78 & 99,999531 & 99,99999974 & $-59,21$ & $-16,87$ \\
\hline $10-9$ & 99,999 & -78 & 99,998375 & 99,99999876 & $-61,79$ & $-19,44$ \\
\hline $10-11$ & 99,999 & -78 & 99,999672 & 99,99999976 & $-58,6$ & $-16,28$ \\
\hline
\end{tabular}

Tabel 6 Merupakan Hasil dari Quality dan Availability didapat dengan Menggunakan Hasil dari simulasi atoll maupun menggunakan Perhitungan link budget. Sebelumnya sudah dibahas mengenai Quality objective dan Availability objectives. Quality objective adalah Nilai ambang batas atau nilai minimal ditentukan untuk melihat keberhasilan suatu Pada daya terima sinyal. Nilai dari Quality Objective adalah minimal -78 dBm sedangkan Availability objective adalah Suatu ukuran kehandalan suatu sistem dalam menyediakan layanan. Nilai dari Availability Objective adalah sebesar 99,999\%. Pada Tabel 4.11 Bisa dilihat dari Link hop 0-1 sampai dengan 10-11 Hampir semua link hop memenuhi nilai minimal dari Parameter Quality objective dan Availability Objective, hanya 2 link hop yang tidak memenuhi Parameter Availability Objective yaitu link hop 6-9 dan link hop 10-9. Pada Link hop 0-1 Terdapat Selisih antara simulasi dan Perhitungan untuk nilai Availability sebesar 2,6282 $\times 10^{-4}$ dan untuk Nilai Quality atau RSL memiliki selisih sebesar 41,39 dBm. Pada Link hop 1-4 Terdapat Selisih antara simulasi dan Perhitungan untuk nilai Availability sebesar 7,8363 $\times 10^{-4}$ dan untuk Nilai Quality atau RSL memiliki selisih sebesar -43,22 dBm. Pada Link hop 3-4 Terdapat Selisih antara simulasi dan Perhitungan untuk nilai Availability sebesar 5,8962 $\times 10^{-4}$ dan untuk Nilai Quality atau RSL memiliki selisih sebesar -42,31 dBm. Pada Link hop 4-2 Terdapat Selisih antara simulasi dan Perhitungan untuk nilai Availability sebesar 6,6059 $\times 10^{-4}$ dan untuk Nilai Quality atau RSL memiliki selisih sebesar -42,31 dBm. Pada Link hop 4-7 Terdapat Selisih antara simulasi dan Perhitungan untuk nilai Availability sebesar 4,1476 $x 10^{-4}$ dan untuk Nilai Quality atau RSL memiliki selisih sebesar -42,29 dBm. Pada Link hop 5-2 Terdapat Selisih antara simulasi dan Perhitungan untuk nilai Availability sebesar 5,7563 $\times 10^{-4}$ dan untuk Nilai Quality atau RSL memiliki selisih sebesar 42,32 dBm. Pada Link hop 6-9 Terdapat Selisih antara simulasi dan Perhitungan untuk nilai Availability sebesar $1,05329 \times 10^{-3}$ dan untuk Nilai Quality atau RSL memiliki selisih sebesar -42,33 dBm. Pada Link hop 7-8 Terdapat Selisih antara simulasi dan Perhitungan untuk nilai Availability sebesar 7,0658 $\times 10^{-4}$ dan untuk Nilai Quality atau RSL

Techno Vol. 19, No. 2, Oktober 2018: $103-112$ 
memiliki selisih sebesar -42,35 dBm. Pada Link hop 7-9 Terdapat Selisih antara simulasi dan Perhitungan untuk nilai Availability sebesar 4,6874 $\times 10^{-4}$ dan untuk Nilai Quality atau RSL memiliki selisih sebesar -42,34 dBm. Pada Link hop 10-9 Terdapat Selisih antara simulasi dan Perhitungan untuk nilai Availability sebesar 1,6237 $x 10^{-3}$ dan untuk Nilai Quality atau RSL memiliki selisih sebesar -42,35 dBm. Pada Link hop 10-11 Terdapat Selisih antara simulasi dan Perhitungan untuk nilai Availability sebesar 3,2776 $\times 10^{-4}$ dan untuk Nilai Quality atau RSL memiliki selisih sebesar 42,32 dBm. Meskipun terdapat selisih yang cukup jauh dari Perhitungan dan simulasi dari Paramater Nilai Availability Maupun nilai Quality atau daya terima Masih dikatakan ideal dan bisa Menyedikan layanan yang baik. Nilai daya terima dari perhitungan dan simulasi masih berada di atas level ambang batas. Semakin Besar Tx Power yang diberikan maka semakin bagus juga nilai dari daya terima atau RSL dan akan berpengaruh pada nilai Availability.

\section{KESIMPULAN}

Berdasarkan Penelitian mengenai Analisa Perencanaan Backhaul Untuk Jaringan Long Term Evolution maka dapat diambil beberapa kesimpulan yaitu dari Hasil Perhitungan dengan mengggunakan capacity planning dibutuhkan sebanyak 12 site untuk mengakomodasi trafik di kota Yogyakarta. Berdasarkan Paramater Reference Signal Received Level ( RSRP) Mempunyai niali rata-rata simulasi sebesar 75,66 dB dan Masih dalam kategori baik. Parameter yang paling mempengaruhi pada Nilai Availability adalah Quality atau Receive Signal Level, semakin besar nilainya Maka semakin Bagus juga Nilai Availability. Nilai Availability rata-rata diperoleh 99,999\% dari Hasil Perhitungan Maupun simulasi, Hanya 2 Link hop yang tidak terpenuhi karena faktor jarak yaitu link hop 6-9 dan link hop10-9. Dari Hasil Simulasi Maupun Perhitungan RSL atau daya terima setiap link hop yang berada di kota Yogyakarta lebih besar dari $-78 \mathrm{dBm}$ yang artinya Quality Objective terpenuhi.

\section{DAFTAR PUSTAKA}

[1] Rizal Danisya Achmad, "Modul Praktikum Komunikasi Seluler," STT Telematika Telkom Purwokerto, Purwokerto, 2016.

[2] U.K.Usman, Fundamental Teknologi Selular LTE. Bandung: Rekayasa Sains, 2011.

[3] Kota yogyakarta Dalam Angka.: BPS Kota yogyakarta, 2017.

[4] Lehpamer,Harvey, Microwave Transmission Network Planning Design and Deployment.: Mac Graw Hill.

[5] Roger,L Freeman, Fundementals Of Telecommunication. New York, 1999.

[6] Roger L, Freeman, Telecomunication Transmission Handbook. New york, 1981.

[7] Hikmahturokhman, A, "Klasifikasi Link Microwave," Akatel Shandy Putra Purwokerto, Purwokerto, 2012.

[8] Hikmahturokhman.A,Wahyudin A,Yuchintya Alia S, Nugraha T, "Comparison analysis of passive repeater links prediction using methods: Barnett Vigants \& ITU models," in New Media Studies (CONMEDIA), 2017 4th International Conference on, 2017, pp. 142-147.

[9] ZH Pradana, A Wahyudin, "Analisis Optimasi Space Diversity pada Link Microwave Menggunakan ITU Models," Jurnal Elektro dan Telekomunikasi Terapan, vol. 4, no. 2, pp. 586-592, 2017.

[10] Dewanti, Intan Erlita, Ade Wahyudin, and Alfin Hikmaturokhman. "ANALISIS PERBANDINGAN PASSIVE REPEATER BACK-TO-BACK ANTENNA DAN PASSIVE REPEATER PLANE REFLECTOR MENGGUNAKAN PATHLOSS 5.0 COMPARATIVE ANALYSIS OF PASSIVE REPEATER BACK-TOBACK PASSIVE REPEATER ANTENNA AND PLANE REFLECTOR USING THE." 
